\title{
Expression of Story: Ethical considerations for participatory, community- and arts-based research relationships
}

\author{
Trish Van Katwyk, Veen Wong and Gabriel Geiger, School of Social Work, Renison University \\ College, University of Waterloo, Canada
}

\begin{abstract}
INTRODUCTION: This meta-research article considers the ethics and efficacy of a nonviolent, "braided" methodology used by a research study called "The Recognition Project." The methodology of The Recognition Project interweaved participatory, community-, and artsbased approaches in an effort to create a cooperative, relationally oriented environment where three distinct communities of interest could contribute respectively - and collaboratively-to the sharing, creation, and public dance performance of stories about self-harm. The three communities of interest were university-based researchers, community-based researchers who had engaged in self-harm, and an artist team of choreographers, a musician, and professional youth dancers. Our article explores some of the experiences, as shared by dancers of the artist team, from narrative interviews following the final dance performance.
\end{abstract}

METHOD: Data were collected through qualitative interviews conducted with six artist team members. A qualitative thematic analysis approach was used to identify the main themes.

FINDINGS: What emerged was an overriding theme about Story and the power issues that came forward due to the personal and the collective aspects of Story. The power issues were related to individual and collective exercise of power, the use of dialogue to build a positive community, and the transformative potential for the artist collaborators to participate in such a study.

CONCLUSION: While participatory, community- and arts-based projects are often taken up with the intention of facilitating research that will not harm, there are important and additional ethical considerations to be made in community-based collaborations that feature difference across perspective, experience, skill, and knowledge.

KEYWORDS: Participatory, community-based research; arts-based research; meta-research; power dynamics; research ethics

It is important for social workers to think critically about the research methodologies that are used to gain an understanding of the human stories and experiences that social workers engage with in their practice. This article, while staged upon a study about self-harm, is, in fact, a critical examination of the research methodology that was used in this exploration. In this article, we intend to inspire readers, as social workers, to think more deeply about the ethics and ethical implications of research practices, as our professional principles and competencies are built upon the knowledge produced through
AOTEAROA

NEW ZEALAND SOCIAL WORK 32(4), 145-157.

CORRESPONDENCE TO: Trish Van Katwyk pvankatw@uwaterloo.ca 
research. When we ask questions of research practice, we can deepen our non-oppressive work by privileging the knowledge that has been gained through non-oppressive research practices.

Many emerging approaches to research represent an effort to dismantle inequitable and oppressive research relationships (de Leeuw \& Hunt, 2018; Ninomiya \& Pollock, 2017; Penak, 2019), to disrupt the 'ivory tower' hold that academia can have on knowledge production (Tuck, 2018; Van Katwyk \& Case, 2017), and to deepen understanding through access to, and privileging of, the significant experiences and knowledges that exist at the community level (Brunner, 2016; de Leeuw \& Hunt, 2018; McTaggart, Nixon, \& Kemmi, 2017; Penak, 2019; Simonds \& Christopher, 2013). Participatory, community-, and / or arts-based research projects have been highlighted for their foundational critical principles of producing knowledge through humanising, equitable practice (Geia, Hayes, \& Usher, 2013; Hill \& Coleman, 2019; Thompson, Miller, \& Cameron, 2016). While research has been described as a violent intervention by many communities and individuals, participatory, community-, and/or artsbased responses are acclaimed as a more ethical way of 'doing' knowledge (Eglinton, Gubrium, \& Wexler, 2011; Penak, 2019). Such approaches to research extend the goals of knowledge production to include critical disruption and socially just societal change (de Leeuw \& Hunt, 2018; Denzin, 2019; Guba \& Lincoln, 1994; Gubrium \& Turner, 2011).

As researchers and social workers, the authors are compelled by the need to disrupt ways of doing research that are experienced as a form of epistemic violence (Brunner, 2016; Held, 2019; Penak, 2019; Spivak, 1988). We wanted to learn about the impact of being a community-based, artist participant in a participatory, community- and artsbased research project. We also aimed to better understand the process, when collaboration across difference, art-making, and art-performing occurs as research.
The Recognition Project began by conducting one-on-one interviews with people who had engaged in self-harm. These interviewees were then invited to become a part of a research team that included university-based researchers. The research team worked intensively with an artist team, collaborating in a dancebased analysis of the interviews and the development of a dance that was performed publicly. The artist team was made up of youth dancers, choreographers, and a musician. After the dance was performed publicly, artist team members participated in one-on-one narrative interviews to share their reflections about participating in this collaborative, community- and arts-based research project. This article is based on the themes that emerged from these artist team member interviews. What the artists shared demonstrates some of the important ethical considerations that are relevant to this research, related to power dilemmas that arise with the telling, creating, and performance of a story that this project, and which many participatory, community-, and arts-based research projects, attempt to illuminate. We suggest that while these projects are often taken up with the intention of facilitating research that will not harm, there are important and additional ethical considerations to be aware of in community-based collaborations that feature difference across perspective, experience, skill, and knowledge.

\section{Background}

Norman Denzin (2018) calls upon researchers to use inquiry for social change. He writes:

There is a pressing need to show how the practices of qualitative research can help change the world in positive ways. It is necessary to continue to engage the pedagogical, theoretical, and practical promise of qualitative research as a form of radical democratic practice. (p. xi)

In promoting justice and emancipation in this radically democratic work, many 
social researchers are wary of power imbalances that may emerge within research relationships. Simultaneously, researchers strive to express knowledge as shared rather than owned and are mindful of how this information is validated to create and support rapid social change. These measures promoting equitable, pro-social, antioppressive approaches exist within (or can be built into) various nonviolent research methodologies, but a question arises: How ethical are they? We suggest that lines of critical inquiry should interrogate the ethical dimensions / contributions of the research methodologies themselves.

Our meta-research asks some probing questions about the ethical commitments and outcomes of the three nonviolent research methodologies used in the Recognition Project. Respectively, these methodologies were participatory action research (PAR), community-based research (CBR), and arts-based research (ABR). These three methodologies were "braided" into a concurrent (as opposed to staged) heterogeneous approach for the Recognition Project. The remainder of this background section will briefly describe the component methodologies of this braided approach, where they intersect, and how each contributes to the study's figurative tensile strength.

\section{Participatory action research}

PAR is an approach to research that encourages the active collaborative involvement, growth and empowerment of research participants throughout the process (Gutberlet, de Oliverira, \& Tremblay, 2017). Research participants and academic researchers engage as co-researchers throughout all research stages, from research idea inception, through data collection, to use and dissemination of findings. This collaborative approach relies on strong ongoing dialogue between co-researchers on the research's ideas, aims, and usability. PAR disrupts the power dynamics within the research process through promoting collaboration, growth and empowerment of co-researchers and community (McTaggart et al., 2017).

PAR can also be described as a social practice, guided by the idea of a more egalitarian, community-led research participation (McTaggart et al., 2017), which diverges from traditional research processes in which knowledge extraction is performed "on or to" participants (de Leeuw, Cameron, \& Greenwood, 2012, p. 184). As such, PAR has gained significant traction in work that involves traditionally marginalized topics or groups (de Leeuw et al., 2012). By bringing forth the perspective of traditionally silenced groups, PAR challenges exclusions by providing an avenue for marginalized groups to engage in more democratic research.

\section{Community-based research}

CBR encourages multiple stakeholders who share collective goals, issues and/or identities within communities of interest (Banks et al., 2013) to collaboratively engage with academic researchers studying complex social problems. CBR defies the traditional research paradigm by cooperating with community stakeholders as full researchers throughout the CBR process, shifting the power of research through relational and multidisciplinary approaches and embracing multiple ways of knowing. This research process is community-driven, with issues and outcomes defined by the community. CBR investigates communitydefined problems by researching with the community as opposed to researching on the community (Lonczak et al., 2013). As such, the community is empowered throughout the process and can shape the research to fit individual and community needs.

Additional time should be allocated for reflection during the research activities, particularly when engaging in powersharing. CBR researchers must acknowledge, rectify and regularly reflect on the process to address the challenges inherent in such 
power-sharing. The equitable involvement of stakeholders in all research stages also increases the likelihood that the proposed collaborative solutions will be meaningful and useful to the community.

\section{Arts-based research}

$A B R$ is an emerging research process that utilises art-based methods and processes to facilitate or engage in answering research questions (van der Vaart, van Hoven, \& Huigen, 2018). ABR can include various artistic genres, such as painting, photography, performing arts, writing, poetry and installation arts. ABR seeks to harness the expressive, immediate and evocative nature of art in individuals and groups in an approach that is widely regarded as mental and physical health promoting in terms of "personal growth, citizen participation, cultural awareness, and community development" (Stein \& Faigin, 2015, pp. 70-71). Due to its creative nature, $A B R$ gives voice to a different perspective by capturing emotions and experiences which may not be generated through traditional cognitively focused EuroWestern research methodologies as typically expressed in formal research publications and presentations (Hill \& Coleman, 2019; Penak, 2019; Tuck, 2018). Additionally, creative methods can be integrated into knowledge translation, allowing for dissemination of the research into communities and spaces that may not have access to traditional research knowledge.

ABR opens up new spaces and discourses that uncover power structures that perpetuate the status quo (Gutberlet et al., 2017). The use of ABR has the potential to create social change through creativity, valued subjective expression, and can also be regarded as a challenge to the standard form of research and academic processes (van der Vaart et al., 2018). ABR's ability to transform and empower communities, coupled with the flexibility and accessibility of engagement, allows for research processes to occur in tandem with CBR and/or PAR.

\section{Braiding methods together}

Researchers who braid together multiple methodologies in community- and arts-based collaborations disrupt the dominant research paradigm through the use of creative, participatory or community-led research (van der Vaart et al., 2018; Wang, Coesmans, Siegesmund, \& Hannes, 2017). Braiding methodologies together in one project is particularly useful for the community and academic researchers interested in applying a creative, non-traditional, and more democratic method of conducting socially engaged research. Additionally, multiple methodologies can support and enrich community impact through a more fulsome understanding of the research (van der Vaart et al., 2018; Watson, 2019). For example, The Recognition Project used CBR to intertwine three diverse communities of interest: community members who had engaged in self-harm; academic researchers; and artists (dancers, choreographers, and a musician). The Recognition Project promoted egalitarian, relational connections between individuals of these communities using PAR methodology, which encouraged storytelling that had been developed and presented through ABR methodology in a public dance performance. Table 1 demonstrates the considerations made by each approach in the context of the research project. This metaresearch explores the experience of some of the collaborating project team members to understand what their experience of participating in a research project that had carefully braided together approaches in order to meet ethical considerations about equity, inclusion, and social change.

\section{Research design: The Recognition Project}

The Recognition Project began with eight narrative interviews with people (aged 16-32) who had engaged in self-harm. The interviewees had been informed that the project would entail creating a dance performance based on the interviews. All of the interviewees were invited to become 
Table 1. Considerations Made for Braiding Research Approaches Together

\begin{tabular}{|c|c|c|c|}
\hline $\begin{array}{l}\text { Research } \\
\text { Approach }\end{array}$ & $\begin{array}{l}\text { Where does it overlap with its } \\
\text { co-methodologies? }\end{array}$ & $\begin{array}{c}\text { Why and how was it used for The } \\
\text { Recognition Project? }\end{array}$ & $\begin{array}{l}\text { Where does it contribute to the } \\
\text { overall 'tensile strength' of this } \\
\text { braided methodology? }\end{array}$ \\
\hline PAR & $\begin{array}{l}\text { PAR and CBR use a collaborative, } \\
\text { relational approach } \\
\text { - PAR and CBR have egalitarian } \\
\text { aims, co-opting community } \\
\text { participants and academics as co- } \\
\text { researchers } \\
\text { - PAR and CBR community-led/ } \\
\text { directed } \\
\text { - PAR and CBR promote relational } \\
\text { exchange/connection as opposed } \\
\text { to transactions of knowledge } \\
\text { - PAR and ABR are participatory } \\
\text { - Social justice/emancipatory focus } \\
\text { - Empowering to the community } \\
\text { - Encourages alternative ways of } \\
\text { knowing }\end{array}$ & $\begin{array}{l}\text { To promote story sharing within } \\
\text { a relational, egalitarian approach } \\
\text { which provided the storytellers } \\
\text { (of personal, unique, traumatic } \\
\text { experiences) with some agency } \\
\text { in how their story was expressed } \\
\text { (i.e., through their feedback to } \\
\text { the choreographer and dancers } \\
\text { throughout the creation of the } \\
\text { dance) }\end{array}$ & $\begin{array}{l}\text { PAR's approach encourages } \\
\text { individual agency to participate } \\
\text { through ongoing dialogue between } \\
\text { co-researchers on the ideas, aims } \\
\text { and usability of the research } \\
\text { - PAR bolsters egalitarian } \\
\text { engagement at a micro level }\end{array}$ \\
\hline CBR & $\begin{array}{l}\text { - CBR and PAR use a collaborative, } \\
\text { relational approach } \\
\text { CBR and PAR have egalitarian } \\
\text { aims, co-opting community } \\
\text { participants and academics as co- } \\
\text { researchers } \\
\text { - CBR and PAR are both community- } \\
\text { led/directed } \\
\text { - CBR and PAR promote relational } \\
\text { exchange/connection as opposed } \\
\text { to transactions of knowledge } \\
\text { - CBR and ABR involve communities } \\
\text { of interest } \\
\text { - Social justice/emancipatory focus } \\
\text { - Empowering to the community } \\
\text { - Encourages alternative ways of } \\
\text { knowing }\end{array}$ & $\begin{array}{l}\text { Like a Venn diagram, CBR reveals } \\
\text { an overlapping centre shared } \\
\text { by three diverse communities of } \\
\text { interest (i.e. academic researcher, } \\
\text { lived-experience community } \\
\text { member, artist team) }\end{array}$ & $\begin{array}{l}\text { CBR provided a larger-scale } \\
\text { approach which tied together three } \\
\text { different communities of interest } \\
\text { into a new and unique community } \\
\text { of interest } \\
\text { CBR was used to build equity and } \\
\text { collaboration between the three } \\
\text { communities of interest at a mezzo } \\
\text { level }\end{array}$ \\
\hline ABR & $\begin{array}{l}\text { - } A B R \text { and PAR are participatory } \\
\text { - } A B R \text { and CBR involve communities } \\
\text { of interest } \\
\text { - Social justice/emancipatory focus } \\
\text { - Empowering to the community } \\
\text { - Encourages alternative ways of } \\
\text { knowing }\end{array}$ & $\begin{array}{l}\text { Used to express themes about } \\
\text { self-harm in alternative ways to } \\
\text { traditional research: the emotionally, } \\
\text { physically and aesthetically } \\
\text { enriched medium of dance }\end{array}$ & $\begin{array}{l}\text { Diverging from traditional research, } \\
\text { ABR was used to create space to } \\
\text { share personal stories of trauma } \\
\text { and vulnerability through an } \\
\text { artistic (dance) performance which } \\
\text { was choreographed to relate the } \\
\text { respective stories/themes of self- } \\
\text { harm shared by the participants } \\
\text { with lived-experience } \\
\text { Dissemination of the stories to the } \\
\text { general public was through dance } \\
\text { performances (i.e., mezzo level) }\end{array}$ \\
\hline
\end{tabular}


involved in the project as co-researchers in the dance-based analysis and knowledge mobilisation of the research findings. Three interviewees were interested and available to participate. A research team was formed made up of three university-based researchers and the three interviewees. An artist team also was developed which was made up of two choreographers, five professionally trained youth dancers (aged 16-25), and a musician.

The eight narrative interviews were thematically analysed by the principal investigator for the first two stages of coding. The themes that existed at this stage were presented to the choreographers to reflect upon as they considered possibilities for the dance development. Dialogue occurred between the choreographers and the researcher who was facilitating the entire project so that the choreographers could process the learning they were encountering in the themes of the firsthand accounts of self-harm. These themes were then presented to the research artist team so that a dancebased analysis could occur collaboratively. They spent five full days together in a dance studio, developing a dance performance based on their interpretation of the themes which had emerged from the interviews. The days were scheduled to begin with a check-in, where members of both teams sat in a circle in the studio. Each person had the opportunity to talk about themselves and to talk about how they were experiencing the project. This was a time when questions could be put forward, plans for the day could be clarified, and mutual dialogue was facilitated. The research team would then leave the studio, where the dancers would begin their warm-up exercises and development of the dance. The research team engaged in training about PAR, CBR, ABR, research memo keeping, arts-based analysis, and knowledge mobilisation.

The research team would return to the dance studio, observing the work of the artists. There were several check-ins throughout each day, and the two teams would talk to each other about the dancebased analysis of the interview themes, carefully considering the ways in which the meanings were being conveyed through the choreographed movements and live musical accompaniment. At the end of each day, the teams concluded with a final check-out where each person had the opportunity to share their experiences of the day and any wishes they had for the following day.

Using this method of analysis and dance development, a 13-minute dance piece was created for knowledge mobilisation. At the end of the week, an in-studio dance was performed and team members invited friends and family to the performance. During this final day, the artists were filmed and photographed. Two months later, two more performances occurred in the community, with a total of almost 120 audience members. The audiences were made up of friends, family, artists, educators, the initial narrative interviewees, researchers, community members, and social service providers. Each performance began with an introduction by the PI and one of the choreographers. Each performance ended with a dialogue that included the researchers, artists, and audience.

\section{Research methods}

In order to gain a deeper understanding of the collaborative process and impact of participatory, community-, and arts-based research, five members of the artist team were interviewed about their experience of this project. The questions for these one-onone qualitative interviews were designed to elicit information about how the artists had been impacted by the collaboration process, including the final public performances. The interviews were analysed using Braun and Clarke's (2012) approach to qualitative thematic analysis, where data are considered for patterns of themes and subthemes. The analysis was based on an interpretation of the themes that emerged throughout the whole of the data set. We focused on the latent level of the themes (Maguire \& 
Delahunt, 2017), exploring the ideologies, conceptions, and assumptions that informed the themes identified by the interviewees. We also used Braun and Clarke's (2012) inductive approach to thematic analysis, where we relied less heavily on the research question, but instead, considered the data to see what was emerging from the interviews (Maguire \& Delahunt, 2017). The authors began by familiarising themselves with the data. We then inductively coded the data individually. After the initial coding, we came together to consider the codes, in order to identify, organise, and define the emerging themes.

\section{Findings}

We asked the interviewed artists about their collaborative working experiences within the Recognition Project. The artists worked with a team of community- and university-based researchers engaged in a dance-based analysis of data about self-harm. Based on this analysis, the artists and researchers jointly developed a dance piece which the artists ultimately performed for several public audiences. What emerged from the interviews was an overriding theme of story, alongside considerations of the power of the individual and power of the community in relation to that story. Individual power was demonstrated through roles and an adherence to the hierarchy that organised those roles. Community power was demonstrated through a loosening up of the rules related to roles that led to a sense of shared responsibility which prompted opportunities for dialogue, acceptance of differences, role collaboration, the inclusion of all voices, and a positive experience of community. With both individual and collective power, the artists described the personal transformation that occurred for them due to unfamiliar experience, new learning, and the potential which comes with performance. Finally, the artists acknowledged the importance of active planning and: 1) how they saw that the planning determined the way in which an organic process was unfolded; 2) further planning could have heightened the preparedness and awareness of all participants; 3) how beneficial the intense timeframe had been; and 4) how important the leadership of this collaboration was.

\section{Story}

Throughout the interviews with the dancers, there were reflections about storytelling. One artist described the dancers as "the people telling the story" (A3). Dance was portrayed as a unique way to share knowledge and stories, through the body and through movements. In this way, knowledge was encountered in an embodied format. As such, the artists also described the subjective expression that could be conveyed through dance: an expression of emotion that each body takes on. Some of the artists felt that, in this embodied form, they could gain a strong connection and even understanding about the story they were recounting: understanding and moving the aspects of self-harm that were being explored. Through learning and practising the choreography of the dance and finally performing it publicly, several artists expressed a growing state of empathy and familiarity around the theme of self harm. One dancer described the sense she gained that the story she was telling was "just a story of humanity" (A2).

There were also concerns shared by the artists about the responsibilities inherent in telling a story which is not entirely one's own. This tension was expressed as the risk of "not portraying the story strong enough" (A6). Another dancer described this sense of responsibility as:

... taking that information and saying it FOR them in a different way is always kind of ... we were the ones essentially being the face of the message, so we had to make sure that it wasn't gonna be cheapening or undermining anything. (A1) 


\section{Individualised power}

Throughout the interviews, power was recognised in a number of ways. As we attempted to understand the enactments of power as they were described in the interviews, we began to identify two distinct but related ways in which power was being discussed: the power of the individual and the power of the community. The power of the individual was established through the roles that team members held in the collaboration, as one artist described:

\section{So, I most appreciated working in a} community, working with a musician in a collaborative stance, really listening to each other's stance. I really appreciated working with the choreographers and dancers, other dancers that came, and the researchers. So that's kind of what I most appreciated about the whole experience was that. Collaboration. (A3)

With its connection to roles, the artists' accounts about power portrayed it as being more static in nature. Depicted as being contained within the body of a person and their respective role, this static power was reportedly a thread which carried through the entirety of the project. At times, there was tension, as the roles and rules connected to those roles were questioned or unknowingly violated by someone who was not aware of the rules. "The two different worlds crashed. People don't necessarily know the rules of each other's world or the unspoken guidelines about how things work" (A1). "There was like a negotiation of 'whose project is it?' Who is, in the end, responsible for it?" (A3). For example, one experience that was discussed in a number of the interviews was related to costumes for the final performance. Some of the researchers proposed an idea about makeup and costume. The choreographers had a different idea. There was some tension about who was going to make the final decision. In the end, according to the rules and roles of the choreographers, the lead choreographer made the final decision. "So that was funny too, just seeing how dancer/non-dancer approaches the visual side of the piece" (A3).

\section{Community/collective power}

As the collaborative work progressed, some of the artists noted a softening in the rigidity of the roles. This reportedly infused a greater sense of shared responsibility into the teams which led to more overlapping and intentional collaborations. "It's a larger undertaking, because there was more to be considered, when you have more perspectives and opinions in the room ... the line was blurred sometimes about what the role [of each participant] was" (A3). This was recognised as being connected to the different levels of dialogue that were happening. Each day began with a checkin, where both teams sat together in a circle and talked about how they were doing, what they carried with them from the day before, and what their hopes / anxieties for the current day were. A check-in happened again after the lunch break, and a checkout happened when the day ended.

I enjoyed having the kind of debrief discussions after each of the days, at the end of the days. So it was usually nice to create, it kinda created a little sense of community, but also managed to keep us on track, and keep all our personal intentions for the piece, for the project, keeping them kind of in line with each other. (A1)

The lunch break happened at the same time for both teams, and as the week went on, more team members were sharing the lunch hour together. As well, when there were mini breaks, members of both teams would go together for coffee, or for a walk, or would sit together and talk. On the second to last day of the project, there was an organised pairing off, where each researcher shared a conversation with an artist. The artists were invited to ask questions of their conversation partner about their knowledge of self-harm. In the interviews, the artists 
referred to these different dialogues as being helpful for building connections.

Another aspect of the community that was discussed in the interviews was the diversity of experience and knowledge that enriched the collaboration. What was noted by the artists about these differences was that everyone's voice and contribution were valued and regarded as contributing to a shared accomplishment: "Everyone was interpreting it differently and ... all interpretations were valid. So it was really neat to see that as all the moving pieces coming together form one thing" (A3).

The impact of dialogue, difference, and equitable worth was the development of a community that felt very positive for the dancers. The experience was described as respectful by many of the artists, with one artist elaborating: "... everybody was coming from a place of curiosity, everyone was curious and open" (A6). Two of the artists referred to the experience as one of solidarity. One artist, in describing what participants gave to this project, said "I would go so far as to say they brought their love" (A4).

\section{Transformation}

The artists also described the ways in which they were changed by their engagement in the project. One of the shifts came by virtue of participating in an experience that was new and unfamiliar. Some of the artists described the discomfort that came with being observed by the researchers: "and being watched ... that's never happened to me ... that was a nightmare [laugh], but again learning to understand the value of the project and the necessities surrounding it and participate as part of it" (A5). Another artist recounted similar initial anxieties:

I was walking into unfamiliar territory, $100 \%$, I didn't know anything about the theme initially and I didn't know the people involved except [name removed] and [name removed] so, you know it was a blank page, you know starting with um, the empty studio, the white canvas, the blank page, the empty lot, silence. All the things that make a fresh beginning, so I have to say that I was in a position to learn. (A4)

As the artists became aware of the unfamiliar stories and experiences shaping their choreography, some conveyed sensing an internal shift as what they were learning settled and even resonated within them. In reference to the final performances, an artist said, "It had been digested somehow and came into being" (A4). A different artist related how "the project really brought up the community idea of finding ways of fighting alienation and isolation" (A2), thus linking connection, isolation, and self-harm in a way that was new and relatable.

Finally, the potential for transformation was noted in the performance aspect of the project. Some of the artists reflected on the potential positive impact similar projects could have in larger communities. One artist described how, with performance, "you have something to say that has never been said" (A1) and another stated that "the artist must leave no stone unturned and then tell us what we see is beautiful" (A4), which can have an important de-stigmatising effect.

\section{Planning for participatory, community-based, arts-based research collaborations}

The artists' descriptions of the project were significantly focused on the process of community building. The days were represented as being "distinctly different" (A2) from one another, with one artist stating that "day by day it's different, person to person, it's different" (A1). Team members worked together responsively, using a flexible and dynamic approach stimulating "organic movement and freedom" (A2) in which the artists "bounced back and forth between fun loving, easy-going, happy vibe and dealing with a heavier subject matter" (A2). Pleasure was expressed: "The ongoing 
process of becoming more of a team, I found that part was really beautiful" (A6). The emergent and organic process signifies an approach to planning that is also processoriented, bringing confidence and trust to a dynamic collaboration shaped in large part by the members of that specific collaboration.

There were a number of observations made that would suggest acknowledgement of the planning that went into this project. The intensive design of the collaboration was appreciated, as it was "intense work and really rewarding. It was nice setting a specific amount of time aside for one thing" (A6). Another artist said, "the week was so fast paced, which created a project where you were totally fine just contributing and doing and moving" (A2). Other interviewees described how helpful it was, with the intensive, five-day schedule. They recounted that each day could move the project forward, picking up from the progress that had been made the day before, without a need to re-visit and recall (i.e., as when dance projects are scheduled week to week). In fact, some of the artists expressed having wanted more time to get things just right. One artist stated, "You need time for something, the subject is very demanding. You need more time to develop it" (A3) while another said, "Extending it another day may be good, if the intention is to have a strong work of art in the end" (A6). Here is where the aesthetic goals of art-making can contribute to a research/art collaboration, with a desire to take the time to create something that is meaningful and beautiful.

Many of the artists also expressed a desire to have had more preparation before the project began in the studio. Further preparation would have allowed for a clarified sense of direction for the artists: “I feel like I wasn't there for certain discussion beforehand when the choreographer and lead researcher talked about their actual goals for the project" (A3). Another artist shared that, while "the researchers researched the topic and understood the complexities of it, I don't know as dancers whether all of us were totally knowledgeable" (A6).

Another level of necessary preparedness was mentioned by almost all of the artists. This had to do with a discourse about selfharm that was brought into the project that created discomfort. One artist described the language, sharing that one of the artists "was talking about people who self-injure as victims and I'm not sure that was the right dialogue to use" (A6). Another artist, in reference to the language of victim noted that "tension was definitely present throughout the workshop" (A3). Another artist, referring to similar discourse that came into the project, stated that it "would've been good to talk about vocabulary" (A1).

What emerged from these discussions was how important careful planning is for the participatory, community-, and arts-based research collaborations. Leadership emerged as a theme, with statements such as "the leader is necessary" (A3). While leadership can be organised according to one's role (e.g., the direction of the choreographer, the mood and tempo created by the musical composer/performer, and the knowledge of the researcher), it was important that overall collaboration was also being coordinated in an organised and sensitive manner. One artist described the leadership approach as one that she found "manageable" (A2). When asked what was meant by this, she responded, "I meant that it was taken in a very delicate way and we very delicately approached the topic and I explored it in a way that, to me ... ended up being safe and comfortable" (A2).

\section{Discussion}

This project, through braiding approaches to collaborative research together, created a place where story occurred in the context of multiple relationships across individual differences. Foucault (1980) asserts that there will always be issues of power where there are relationships. He also describes the ways in which power can work to subjugate 
knowledges (Foucault, 1977). Subjugated knowledges are those knowings and experiences that are discounted as invalid. This project worked to create a relational environment where power was exchanged and exercised in ways that strengthenedrather than harmed-community.

This project facilitated space for a different discourse on self-harm to be expressed in an embodied form through dance. The connections that the artist team created, through multiple dialogues with the research team, enriched the way they understood and expressed aspects of self-harm within the dance and in themselves. This resulting change described by the artists highlights the impact of participatory, community-, and arts-based research projects on dialogue, sense of community, and understanding of stigmatised topics.

The researcher has ethical responsibilities regarding the ways in which power, both individual and collective, is distributed. Inequitable distribution of power between researcher and community partnerships can limit participation (Wilson, Kenny, \& Dickson-Swift, 2018). Inequitable and unfair exercise of power can lead to the decay of positive safe spaces within a research project. Consequently, researchers may unwittingly disempower participants when researching stigmatised topics and experiences such as self-harm. This disempowerment has the potential to harm participants and can affect how a story is understood, processed, and expressed, potentially creating spaces that are experienced as negative or unsafe to those involved (de Leeuw \& Hunt, 2018; Geia et al., 2013; Wilson et al., 2018).

Additionally, researchers must be aware of the limitations of ethics review processes through the research ethics board (REB) in participatory, community-, and arts-based research. Many of the concerns surrounding the ethical responsibility of power echo those noted under CBR and PAR research. Ethics review processes can provide a layer of safety to protect research participants from undue harm, however, they may disregard the collective and relational nature (Wilson et al., 2018; Wood, 2017) of participatory, community-, and arts-based research processes. The procedures called upon by REBs are often insufficient to ensure that community participation and distribution of power during all stages in the research process are participatory and equitable (Wood, 2017). Researchers interested in facilitating a participatory, community-, and arts-based project have obligations to understand how power, within the group and for each member, is experienced and manifested. Researchers should be prepared to provide leadership and actively facilitate action to address any misalignment of power throughout the research process.

Providing active leadership and avenues for participants to voice and address power differentials (e.g., fostering dialogue between participants) can help create positive space while strengthening and empowering participants. In our interviews with the artist team, some artists commented on the ways different dialogues occurred and how these dialogues facilitated the equalisation of power dynamics. The artists, who expressed initial discomfort in speaking or voicing ideas during discussions early in the project for fear of saying the "wrong" thing, stated that the daily check-ins after communal lunches and breaks with the researchers put them more at ease to engage in candid conversation. Although it was not necessary for our artist and researcher groups to formally discuss power dynamics, researchers should facilitate space and time for participants to engage in ongoing dialogical collaborations in participatory, community-, and arts-based projects.

This project and all of its participants worked to valorise community through the collective analysis and performance of a story. The findings present valuable information about the possibilities of participatory, community-, and arts-based research, as well as the responsibilities of the researcher. Due to the diversities that constitute many community- 
based collaborations and the subjective expression that is inspired in much artsbased research, there are inherent inequitable power dynamics within these projects. The power enactments can come from individual as well as collective sites. We do not suggest that power dynamics only create difficulties and obstacles. Rather, we propose that individual and collective power enactments invite unique ethical considerations in these kinds of projects. Dilemmas about power enactments in collaborative, communitybased research relationships are inevitable, and must be confronted with respect and reflexivity (Ninomiya \& Pollock, 2017). An empowering, engaged leadership is called upon (Flicker et al., 2015; Malott, 2010; Tucker, Williams, Roncoroni, \& Heesacker, 2017). Even as participatory, community-, and arts-based projects are largely processfocused, we contend that it would be unethical for the facilitating researchers to passively observe the process as it unfolds. The inherent power differentials and accompanying dilemmas must be addressed, and the facilitating researchers have the responsibility to steward this process by utilising tools and strategies to care for the project and its participants. As researchers, we need to ensure that we are leading in a way that will strengthen and empower both the research process and the collaborating participants.

\section{Conclusion and implications}

Braiding together participatory, community-, and arts-based approaches to research prioritises equitable, action-oriented explorations that can have immediate benefits for those involved in the research. The collaborative nature of such a braided approach to research, particularly as it incorporates the expression and performance of a story, calls upon ethical considerations of power and accompanying responsibilities for the researcher who is facilitating the project. In the findings of our meta-research exploration, there emerged a consideration of story, and how both the power of the individual and the power of the community were accountable to the transformative possibilities of collaborative, arts-based, knowledge production that needed careful planning for an ethical process to occur. An important implication is in reference to the considerations that need to be made beyond those existing in many institutional research protocols (i.e., those used by many REBs). Our findings suggest that researchers should conduct a close interrogation of the power dynamic, as well as the discourses that can shape the way in which stories are represented, reproduced, and performed. Furthermore, our research suggests that such projects need to be carefully planned and facilitated, using dialogue that can strengthen relationships and create opportunities for an exercise of power that can, at both individual and collective levels, create an artistic and validating expression of story.

Acknowledgements This project was made possible with a grant from the Astley Family Foundation.

Accepted 7 October 2020

Published 15 December 2020

\section{References}

Banks, S., Armstrong, A., Carter, K., Graham, H., Hayward, P., Henry, A., ... Strachan, A. (2013). Everyday ethics in community-based participatory research. Contemporary Social Science, 8(3), 263-277. https://doi.org/10.1080/2 1582041.2013.769618

Braun, V., \& Clarke, V. (2012). Thematic analysis. In H. Cooper, P. M. Camic, D. L. Long, A. T. Panter, D. Rindskopf, \& K. J. Sher (Eds.), APA handbooks in psychology ${ }^{\circledR}$. APA handbook of research methods in psychology, Vol. 2. Research designs: Quantitative, qualitative, neuropsychological, and biological (pp. 57-71). American Psychological Association. https://doi.org/10.1037/13620-004

Brunner, C. (2016). Knowing suicide terrorism? Tracing epistemic violence across scholarly expertise. Ethiopian Renaissance, 3(1), 3. http://ejol.aau.edu.et/index.php/ ERJSSH/article/view/1701/1206

de Leeuw, S., Cameron, E., \& Greenwood, M. (2012). Participatory and community-based research, Indigenous geographies, and the spaces of friendship: A critical engagement. Canadian Geographer / Le Géographe Canadien, 56(2), 180-194. https://doi. org/10.1111/j.1541-0064.2012.00434.x

de Leeuw, S. \& Hunt, S. (2018). Unsettling decolonizing geographies. Geography Compass, 12(7), e12376. https://doi.org/10.1111/gec3.12376 
Denzin, N. K. (2018). The qualitative manifesto: $A$ call to arms. Routledge.

Denzin, N. K. (2019). The death of data in neoliberal times. Qualitative Inquiry, 25(8), 721-724. https://doi. org/10.1177/1077800419847501

Eglinton, K.A., Gubrium, A., \& Wexler, L. (2011). Digital storytelling research and practice. In S. N. Hess-Biber (Ed.), Handbook of emergent technologies in social research (pp. 469-491). Oxford University Press.

Flicker, S., O'Campo, P., Monchalin, R., Thistle, J., Worthington, C., Masching, R., ... Thomas, C. (2015). Research done in "a good way": The importance of indigenous elder involvement in HIV community-based research. American Journal of Public Health, 105(6), 1149-1154. https://doi.org/10.2105/AJPH.2014.302522

Foucault, M. (1977). Discipline and punish: The birth of the prison (Alan Sheridan, trans.). Random House.

Foucault, M. (1980). Power/knowledge: Selected interviews and other writings, 1972-1977. Vintage.

Geia, L. K., Hayes, B., \& Usher, K. (2013). Yarning/ Aboriginal storytelling: Towards an understanding of an indigenous perspective and its implications for research practice. Contemporary Nurse, 46(1), 13-17. https://doi. org/10.5172/conu.2013.46.1.13

Guba, E. G., \& Lincoln, Y. S. (1994). Competing paradigms in qualitative research. In N. K. Denzin \& Y. S. Lincoln (Eds.), Handbook of qualitative research (pp. 105-117). Sage.

Gubrium, A., \& Turner, K. N. (2011). Digital storytelling as an emergent method for social research and practice. In S. N. Hesse-Biber (Ed.), Handbook of emergent technologies in social research (pp. 469-491). Oxford University Press.

Gutberlet, J., de Oliverira, B. J., \& Tremblay, C. (2017). Artsbased and participatory action research with recycling cooperatives. In L. L. Rowell., C. D. Bruce., J. M. Shosh., \& M. M. Riel (Eds.), The Palgrave international handbook of action research. Palgrave Macmillan.

Held, B. S. (2019). Epistemic violence in psychological science: Can knowledge of, from, and for the (othered) people solve the problem? Theory \& Psychology. https://doi.org/10.1177/0959354319883943

Hill, R. W., Sr., \& Coleman, D. (2019). The two row wampumcovenant chain tradition as a guide for indigenousuniversity research partnerships. Cultural Studies $\leftrightarrow$ Critical Methodologies, 19(5), 339-359. https://doi. org/10.1177/1532708618809138

Lonczak, H. S., Thomas, L. R., Donovan, D., Austin, L., Sigo, R. L., Lawrence, N., \& Tribe, S. (2013). Navigating the tide together: Early collaboration between tribal and academic partners in a CBPR study. Pimatisiwin, 11(3), 395. Retrieved from http://www.pimatisiwin.com/online/ wp-content/uploads/2014/02/05LonczakThomas.pdf

Maguire, M., \& Delahunt, B. (2017). Doing a thematic analysis: A practical, step-by-step guide for learning and teaching scholars. All Ireland Journal of Higher Education, 9(3). http://ojs.aishe.org/index.php/aishe-j/ article/view/335

Malott, C. (2010). Policy and research in education: A critical pedagogy for educational leadership (Vol. 4). Peter Lang.

McTaggart, R., Nixon, R., \& Kemmi, S. (2017). Critical participatory action research. In L. L. Rowell., C. D. Bruce., J. M. Shosh., \& M. M. Riel (Eds.),
The Palgrave international handbook of action research. Palgrave Macmillan.

Ninomiya, M. E. M., \& Pollock, N. J. (2017). Reconciling community-based indigenous research and academic practices: Knowing principles is not always enough. Social Science \& Medicine, 172, 28-36. https://doi. org/10.1016/j.socscimed.2016.11.007

Penak, N. (2019). Walking Toronto's red road: The story pathways of indigenous social workers (Unpublished doctoral dissertation). University of Toronto, ONT. Retrieved from https://tspace.library.utoronto.ca/ bitstream/1807/97575/3/Penak_Nicole_201911_PhD_ thesis.pdf

Simonds, V. W., \& Christopher, S. (2013). Adapting western research methods to indigenous ways of knowing. American Journal of Public Health, 103(12), 2185-2192. https://doi.org/10.2105/AJPH.2012.301157

Spivak, G. C. (1988). Can the subaltern speak? MacMillan.

Stein, C. H., \& Faigin, D. A. (2015). Community-based arts initiatives: Exploring the science of the arts. American Journal of Community Psychology, 55, 70-73. https://doi.org/10.1007/s10464-014-9698-3

Thompson, N. L., Miller, N. C., \& Cameron, A. F. (2016). The indigenization of photovoice methodology: Visioning indigenous head start in Michigan. International Review of Qualitative Research, 9(3), 296-322. https://doi.org/10.1525/irqr.2016.9.3.296

Tuck, E. (2018). Biting the university that feeds us. In M. Spooner \& J. McNinch (Eds.), Dissident knowledge in higher education (pp. 21-40). University of Regina Press.

Tucker, C. M., Williams, J. L., Roncoroni, J., \& Heesacker, M. (2017). A socially just leadership approach to community-partnered research for reducing health disparities. The Counseling Psychologist, 45(6), 781-809. https://doi.org/10.1177/0011000017722213

van der Vaart, G., van Hoven, B., \& Huigen, P. P. P. (2018). Creative and arts-based research methods in academic research. Lessons from a participatory research Project in the Netherlands. FQS, 19(2), Article 19.Retrieved from http://www.qualitative-research.net/index.php/fqs/article/ view/2961

Van Katwyk, T., \& Case, R. (2017). From suspicion and accommodation to structural transformation: Enhanced scholarship through enhanced community-university relations. Engaged Scholar Journal, 2(2), 25-43.

Wang, Q., Coemans, S., Siegesmund, R., \& Hannes, K. (2017). Arts-based methods in socially engaged research practice: A classification framework. Art/ Research International: A Transdisciplinary Journal, 2(2), 5-39. https://doi.org/10.18432/R26G8P

Watson, A., (2019). Methods braiding: A technique for arts-based and mixed-methods research. Sociological Research Online, 1-18. https://doi. org/10.1177/1360780419849437

Wilson, E., Kenny, A., \& Dickson-Swift, V. (2018). Ethical challenges in community-based participatory research: A scoping review. Qualitative Health Research, 28(2), 189-199. https://doi.org/10.1177/1049732317690721

Wood, L. (2017). The ethical implication of communitybased research: A call to rethink current review boards requirements. International Journal of Qualitative Methods, 16, 1-7. https://doi. org/10.1177/1609406917748276 